\title{
TÜRKiYE'DE SIYASAL GÜVEN: NEDENLERI VE SONUÇLARI
}

\author{
Yrd. Doç. Dr. Birol Akgün \\ Selçuk Üniversitesi \\ Iktisadi ve Idari Bilimler Fakültesi
}

\section{Õzet}

Bu çalışma, Türkiye’deki siyasal güvensizliğin boyutların, vatandaşların siyasal kurumların işleyişinden neden memnun olmadıklannı ve artan seçmen hoşnutsuzluğunun Türk siyasal yaşamındaki sonuçlarını incelemektedir. Önce Dünya Değerler Araştırması verileri kullanılarak vatandaşlann siyasal topluma, demokratik rejime ve rejim performansına yönelik güven düzeyi incelenmektedir. Ardından regresyon yöntemi kullanılarak siyasal güveni etkileyen faktörler belirlenmeye çahşılmıştır. Araştırma, vatandaşların siyasal topluma ve demokratik rejime büyük oranda bağlılı ve güven duyduklarını ortaya koyarken, halkın siyasal kurumların işleyişinden hoşnut olmadiğın göstermektedir. Istatistiki verilerin analizinden anlaşlmaktadır ki Türkiye'de siyasal güvensizliğin en önemli nedeni halkın genel olarak siyasal kurumların performansını yetersiz bulmalarıdır. Diğer önemli bir neden de vatandaşların yönetim sürecinde yaygın adaletsizlikler ve haksızlıklar (rüşvet, adam kayırma, yolsuzluk vs.) olduğu inancıdır. Siyasal güvensizliğin davranı̧sal sonucu ise hoşnutsuz seçmenlerin popülist protesto partilerine daha fazla destek verme eğiliminde olmalandır. Bunun aksine, güven düzeyi yüksek seçmenlerin ise daha çok seçime katılmama biçiminde davranış sergilediği anlaşılmaktadır.

\section{Political Trust in Turkey: Causes and Consequences \\ Abstract}

This study seeks to explore sources of political support and citizen dissatisfaction with the government and its consequences in Turkish politics. First, the study examines citizen support for political society, democratic regime, and regime performance using the World Values Surveys, 1990-91 and 1996-97. Second, the study attempts to explain determinants of citizen frustration and political support in Turkey. This paper finds that there is overwhelming support for the democratic regime and political society in Turkey, but a majority of citizens are dissatisfied with governmental institutions. The study provides evidence that citizen frustration in Turkey is related to their perception of poor government performance, and unfairness and unresponsiveness in the governing processes. In addition, the study suggests that while highly trustful and optimistic voters tend to withdraw from participation in elections, frustrated voters are more likely to support populistic protest parties. 


\section{Türkiye'de Siyasal Güven: Nedenleri ve Sonuçları}

\section{Giris}

Ülkemizde halkın siyasal sisteme, partilere ve genel olarak tüm kurumlara güveninin azaldığı son yıllarda yaygınlaşan bir kanı haline geldi. Güven erozyonun 1990'larda başladığı ve artan bir trend halinde 2000'li yıllarda dibe vurduğu pek çok kamuoyu araşturması tarafından da doğrulanıyor. $O$ kadar ki vatandaşlann sadece siyasal partiler ve meclis gibi kurumları değil Anayasanin girişinde ifade edilen devletin kutsal olma niteliğini dahi belki de ilk kez sorgulamaya başladıkları belirtiliyor. Son on yılda yapılan seçimlere bakıldığında da aslında yukarıdaki iddiaların dolaylı olarak doğrulandığı görülür. Seçmenler, bir yandan merkezdeki partilerden desteğini çekerken öte yandan sistemin dışında ya da kenarında yer alan marjinal partilere oy vermeyi tercih etmektedirler. Bunun sonucu ise bir taraftan alışılmışın dışında bir seçmen oynaklığı (electoral volatility) öte yandan partiler sisteminde görülen aşırı parçalanma ve kısa süreli, istikrarsız, karar alma gücü zayıflamış koalisyon hükümetlerinin birbirini izlemesidir. Böylece Türkiye'nin 1980'lerde başlattığı siyasal ve ekonomik reform süreci hızını 1990'larda kaybederken statüko savunuculan ve günü kurtarma politikaları revaç bulmaya başladı. Şüphesiz ardı arkası kesilmeyen siyasi ve ekonomik krizler, medyada hiç eksik olmayan skandallar ve yönetme kapasitesi düşük koalisyon hükümetleri, seçmenlerin siyasal sisteme ve yerleşmiş kurumlara (siyasal partiler, meclis, hükümet, bürokrasi) yönelik tutumlarındaki köklü değişikliğin ana nedenleri arasındadır.

Siyaset bilimciler kurumlara karşı gösterilen aşın güvensizliğin, halktaki yaygın moral bozukluğunun, artan hayal kırıklıklarının ve siyasal yabanclaşmanın bir demokratik sistem için tehlikeli ve sağlıksız bir gösterge olduğunu, çünkü uzun vadede bu güven erozyonunun kurulu sistemin meşruluğunu yok edeceğini savunmaktadırlar (FINIFTER, 1970). Bazılarn ise halkla hükümet arasındaki sürekli bir güven bunalımının, hükümetin tartışmalı ancak kamu hayatı için son derece kritik gelişmeler karşısında karar alma 
kabiliyetini zayıflatacağını ve daha da önemlisi kriz anlannda hükümetlerin yönetme kabiliyetlerini engelleyeceğini belirtmektedirler (EASTON, 1975; HIBBING/THEISS-MORSE, 1995). Örneğin ünlü siyaset bilimci Easton "halk desteğinin belli bir minimum düzeyin altına düşmesi durumunda her çeşit siyasal sistemin varlığının tehlikeye düşeceğini" söylemektedir (EASTON, 1965: 220).

Türkiye gibi gelişmekte olan ülke demokrasilerinde ise siyasal güven daha da önem kazanur. Çünkü bu gibi ülkelerde rejim, yerleşmiş demokrasilerdeki gibi halkın kayıtsız şartsız desteğine sahip değildir. Profesör Norris'in (1999) belirttiği gibi, demokratik yolla iktidara gelen hükümetlerin başarısız olduğu kanısı halk arasında yaygınlaşmaya başlarsa bu tutum zamanla demokrasinin bizzat kendisine olan inancı da zayıflatabilir. Bu da gelişmekte olan demokrasilerin kurumsallaşmasını engelleyecektir. Böyle durumlarda ortaya çıkan tehlike halkın eski otoriter rejimlere dönmeyi istemesinden ziyade zaten meşruiyeti zayıf olan demokratik rejimin liderlik tartı̧malan, etnik çatı̧̧malar ve siyasal ve sivil hakların kullanım alanının daralmasıyla giderek zayıflama ihtimalidir (NORRIS, 1999: 2). Son olarak, seçimle iş başına gelen sivil iktidarların sosyo-ekonomik sorunları çözmede sürekli başarısızlık göstermeleri ülkedeki tarafsız fakat zinde güçlerin (i.e. silahlı kuvvetler) kamu çkarın korumak adına politik alana müdahale etmesini kolaylaştıracaktur.

Karşılaşturmalı siyaset bilimi literatüründe siyasal güvenle ilgili araşturmalar daha çok gelişmiş ülkeler üzerine yoğunlaşmakta ve gelişmekte olan ülkelerdeki siyasal güven ve demokratik istikrar arasındaki ilişkiler üzerinde yeterince durulmamaktadır. Uzunca bir demokratik geçmişe sahip, gelişmekte olan bir ülke olan Türkiye'de halkın siyasal kurumlara olan güveninin nasıl değiştiğinin incelenmesi oldukça öğretici olacaktır. Sayın Özbudun'un vurguladığı gibi, Türkiye'de müzminleşen sorunlar, özellikle artan mali, sosyal ve ekonomik sıkıntular ve yaygın siyasal yozlaşma son yıllarda seçmenler arasında derin bir karamsarlık ve hayal kırıklı̆̆ yaratmıştır. Seçim zamanunda pek çok seçmen artık sadece en az zarariı olan (ehven-i şer) seçeneğe bakarak oy vermektedir (ÖZBUDUN, 1996). Daha da önemlisi, Türkiye'nin elli yllık demokrasi tarihinde üç kez askeri müdahale tecrübesi yaşanmıştır. Bazılarının "post-modern darbe" olarak adlandırdığı ve yaygın olarak "28 Şubat süreci" olarak bilinen ve ordunun dolaylı yoldan siyasal hayata müdahalesini anlatan son gelişmeler de henüz Türk demokrasisinin yeterince kurumsallaşamadığın göstermektedir (SALT, 1997; ÇANDAR, 1999). Her ne kadar sistem içinde kendisine belli bir "siyasal otonomi" alanı yaratan silahlı kuvvetlerin (SAKALLIOĞLU, 1996) bu son müdahalesinin gerçekleşmesinde başka nedenler varsa da, yönetme kabiliyeti zayıflamış hükümetlerin, halk desteğini yitirmiş kurumların (siyasal partiler gibi) ve meşruiyeti düşük bir demokratik sistemin de bunu kolaylaşturdığı inkar edilemez. Zaten gerek 1960 
gerekse 1980 darbeleri siyasal güvenin dibe vurduğu anlarda ve halkın alkışlan arasında iktidara gelmiş ve geniş kesimlerden de destek almıştur.

Geleneksel olarak Türk halkının devlete ve onun kurumlarına karsı aşırı güven beslediği bilinmesine rağmen (KINZER, 1999) Türkiye'de son yillarda yapılan bütün kamuoyu araştırmalar halkın hem kurumlara hem de yönetim sürecine güveninin azaldığın ortaya koymaktadır (ÇANDAR, 1999). Hızlı güven erozyonun arkasında yatan nedenier ise henüz akademik olarak incelenmiş değildir. Ülkemizdeki bu sorunun incelenmesi hem teorik olarak halktaki siyasal kurumlara karşı tutumların nasıl değiştiğinin anlaşılması hem de bunun siyasal ve sosyal alandaki sonuçlarının ortaya konması bakımından önem arz etmektedir. Örneğin son günlerde Türk ekonomisinde yaşanan krizler ve piyasalarda yaşanan aşırı dalgalanmaların siyasal güvenle ilgili olduğu sık sik dile getirilmektedir, $\mathrm{ki}$ bu iddiaların veriler kullanarak incelenmesi gerekmektedir. Iş̧e bu çalışmanın amaa da halkın hükümete ve diğer siyasal kurumlara yönelik artan memnuniyetsizliğin ve aşırı güvensizliğin kaynakların incelemek ve bunun Türk siyasal yaşamındaki sonuçlanns ortaya koymaktır. Çalışmada Dünya Değerler Araştırması (1990-91 ve 1996-97) verileri kullanılmıştır. Siyasal güvenin sadece nedenleri değil özellikle seçmen davranışıyla ilgili sonuçları da incelenmektedir. Çalışmada istatistiki analiz yöntemi olarak hem korelasyon hem de regresyon teknikleri kullanilmaktadir.

\section{Siyasal Güven Kavramı}

Siyaset bilimi literatüründe siyasal güven kavramınn tanımı çok net değildir. Yerine göre "güven", "yaygın destek", ya da "halk desteği" kavramları da ayn anlamda kullanımaktadır. Bu konularda ilk çalş̧malan yapan David Easton, güven kavramın "siyasal otoritelere ya da rejime yönelik yaygın destek" olarak tanumlamıştır (EASTON, 1975). Daha özel anlamda güven şu şekilde tanumlanabilir. Halkın, siyasal sistemin herkes için eşit ve adil sonuçlar doğuran politikalar üretebileceğine ilişkin yaygın inancın, ya da vatandaşlann kendi siyasal inanç ya da moral değerlerine göre sorumlu siyasal otoriteler ve kurumlann performansınun değerlendirilmesine dayanan bir yargıyı ifade eder (MILLER/ LISTHAUG, 1990; MULLER/JUKAM/SELIGSON, 1982). Ünlü The Civic Culture araştırmasının yazarları (ALMOND/VERBA, 1965: 63) ise bu kavramı "sistem etkisi" olarak ifade etmişler ve "bir bütün olarak sisteme yönelik genelleşmiş tutumlar" olarak tanımlamışlardır. Biz bu çalışmamızda özel ya da yaygın anlamda güven ayrımı yapmaksızın Miller ve Listhaug (1990) tarafından geliştirilen şu tanımı esas alacağız. Yönetime güven, siyasal sistemin vatandaşlann taleplerine duyarlı olduğuna ve sürekli bir gözetim olmasa dahi sistemin doğru olanı yapacağına ilişkin kanaatlerinin bir özetidir. 
Ampirik çalışmalarda siyasal güvenin göstergesi olarak kişilerin kendilerinin de bir parçası olduğu siyasal topluma, siyasal sisteme ve seçimle iş başına gelmiş iktidara yönelik duyduklan güveni ifade etmekteydi. Son yıllarda ise kısmen alan araştırmalarının yaygınlaşması sonucu bazı yazarların siyasal güvenin yöneldiği kurumlan beş ayn kategoride incelediği görülmektedir (NORRIS, 1999). Bunlar siyasal toplum, rejimin ilkeleri, rejimin performansi, rejimin kurumları ve siyasal aktörlere yönelik güvenden oluşur. Her ne kadar bu yeni yaklaşım daha ayrıntılı bir güven incelemesini yansıttyorsa da biz bu çalışmamizda geleneksel üçlü ayrıma (siyasal toplum, siyasal rejim ve iş başındaki iktidar) bağlı kalacağız. Güven kavramunın anlamına yönelik bu kısa girişi yaptıktan sonra, Türk toplumunda bu üç kuruma yönelik güveni incelemeye geçmeden önce güvensizliğin altında yatan nedenler konusunda kısa bir teorik tartışma yararlı olacaktır.

\section{Siyasal Güvensizliğin Açıklanması}

Gelişmiş ülke demokrasilerinde yapılan pek çok araştırma vatandaşların siyasal kurumlara ve liderlere yönelik güveninde genel bir düşüş trendi olduğunu saptamıştır (NORRIS, 1999; NYE/ZELIKOW/KING, 1997). Fakat bu fenomenin nasıl açıklanması ve yorumlanması gerektiğine ilişkin tartş̧malar sosyal bilimciler arasında hala devam etmektedir (MILLER/LISTHAUG, 1999). Halk Hükümete Neden Güvenmez adl önemli (NYE/ZELIKOW/KING, 1997) araştırmanın yazarlan, yurttaşların siyasal sistemden hoşnutsuzlukların açıklamaya yönelik on iki ayrı model önermişlerdir. Bunlar, ekonomik performans yaklaşımından, post-modern değerlerin yükselişi teorisine ve medyanın etkisine değin geniş bir bakış açısın yansıtmaktadır. Aslında güvensizlik doğuran bütün bu nedenleri iki ana başlık althnda incelemek mümkündür: Birincisi, güven erozyonunu siyasal sisteme yönelik aşırı talep ve beklentilerin karşılanmamasından kaynaklanan hoşnutsuzluklarla açıklayan yaklaşım (demand overload theory), ikinsisi ise güvensizliği siyasal sistemin işleyiş sürecinde ortaya çlkan haksızlık ve adaletsizliklerden doğan hoşnutsuzluklardan kaynaklandığını savunan yaklaşım (procedural frustration).

Aşırı talep artışıı esas alan yaklaşıma göre ikinci dünya savaşından bu yana vatandaşların hükümetlerden talep ve beklentileri hızla artmıştır. Artan taleplerin hepsinin hükümetlerce yerine getirilebilmesi mümkün olmadığı için vatandaşlarda kaçınılmaz olarak siyasal sisteme yönelik hoşnutsuzluk da artmaktadır ve bunun sonucunda da meşruluk krizleri ortaya çıkmaktadır (EASTON, 1965; LIPSET/SCHNEIDER, 1987; MILLER/LISTHAUG, 1999). Bu görüşe göre, bir ülkede rejimin meşruluğu esas olarak hükümetin iş başarma yeteneğinin (performansının) vatandaşlarca nasıl değerlendirildiği ile ilgilidir. Bazı araşturmalar (WEATHERFORD, 1987), hükümetin ekonomik alandaki başarısı ile vatandaşların hoşnutsuzluğu ve hükümete güven arasında güçlü bir 
ilişkinin var olduğunu göstermişken diğer bazılan (LAWRANCE, 1997) ise hükümete güven ile ekonomik performansı arasındaki ilişkinin iddia edildiği gibi çok da güçlü olmadığı sonucuna varmıştır.

Güven kaybının kaynağını siyasal süreçteki olumsuzluklara bağlayan ikinci görüşe göre ise önemli olan hükümetlerin izlediği politikalann sonuçları değil bu politikalann uygulama sürecidir. Örneğin bu konuda Amerika'daki halkın hükümetlere neden güvensizlik duyduğuna ilişkin önemli bir çalışmaya göre (HIUBBING/THEISS-MORSE, 1995), vatandaşlann yönetim sürecinin adaletsiz olduğuna ve politikacalann kendi taleplerine duyarsız olduğuna ilişkin kanaatleri en az uygulanan politikalann sonuçlan kadar vatandaşların hükümete ve kurumlara duyduğu güvensizliği etkilemektedir. Vatandaşlar yasama medisindeki kavgalardan, medyadaki rüşvet ve yolsuzlukla ilgili haberlerden ve sürekli tekrar eden hükümet krizlerinden son derece rahatsız olurlar ve bu da uzun dönemde güven duygusunu zedeler. Diğer siyaset bilimciler de bu yaklaşımın önermelerine katılmaktadırlar (EASTON, 1995; MILLER, 1974).

Her ne kadar yukarıda aktarılan araştırmalar son yllarda yerleşmiş demokrasilerde dahi halk arasında şüpheciliğin arttığını ve siyasal kurumlara yönelik güvensizlik duygularınun yoğunlaştığını aktanyorlarsa da bunun sonuçlarınin ne olacağı konusunda kesin bir öngörüde bulunamamaktadırlar. Bununla birlikte bazı çalışmalar siyasal sisteme yönelik artan güvensizlik ve hoşnutsuzluk ile protesto oyları arasında güçlü bir ilişkinin var olduğunu göstermektedir (MILLER VE LISTHAUG, 1990). Bazılan artan şüpheciliğin siyasal katılmayı azaltacağını iddia ederken (TEXEIRA, 1992) bazılan da sisteme güvensizliğin vatandaşlan olağandışı siyasal davranş̧lara itebileceğini öne sürmektedir (MULLER/JUKAM/SELIGSON, 1982). Her ne kadar güven erozyonunun sonuçlan şu an kestirilemese de sosyal bilimciler artan güvensizliğin mutlaka ciddiye alınması gereken bir uyarı olduğu konusunda birleşmektedirler (NYE/ZELIKOW/KING, 1997).

\section{Araştırma Verileri ve Yōntem}

Türkiye'de siyasal güvenin incelendiği bu çalışmada veri olarak Dünya Değerler Araştırması'nın (World Values Survey) Türkiye ayağında gerçekleştirilen anket sonuçları kullanulmıştur. Değerler araşturması, Michigan Üniversitesi profesörlerinden Ronald Inglehart tarafından koordine edilmiş ve kırkı aşkın ülkede uygulanmıştur. Türkiye ayağı ise Boğaziç̣ Üniversitesinden bir grup akademisyenin öncülüğünde gerçekleştirilmiştir. Ilki, 1990-91, ikincisi de 1996-97 döneminde yapılmıştır. Araştırmanın ilk ayağında Mesut Yılmaz başkanlığındaki ANAP hükümeti işbaşındayken, ikinci ayağı Necmettin Erbakan başkanlığındaki Refahyol hükümeti dönemine rastlamıştır. Araştırma 
evrenini Türkiye'deki seçmen yaşına gelmiş, 18 ve üzeri, vatandaşlar oluşturmaktadır. Daha önceden Türk seçmenleri üzerinde yapılan benzer bir çalışmanın olmaması nedeniyle öncelikle her iki çalışmada ortaya çıkan genel bulgular karşılaştırılarak Türk seçmenin siyasal kurumlara bakışına yönelik bir güven haritası çıarılacak, ardından da çok-değişkenli analiz tekniği kullanılarak güvenin ardında yatan nedenler aynntılı biçimde ve derinlemesine incelenecektir. ${ }^{1}$

\section{Türkiye'de Siyasal Güvenin Boyutları}

Dünya Değerler Araşturmasi'nda siyasal destek ve güveni ölçmeye yönelik pek çok soru sorulmuştur. Bu çalışmada Easton'un (EASTON, 1975) üçlü sınuflandırması kullanılarak siyasal toplum, rejim ve hükümet kurumlanna ilişkin halk desteği incelenecektir.

5.1. Siyasal topluma güven: Günümüzde bireyler belli bir ulus devletin sınırları içinde yaşamaktadır ve sosyolojik ve siyasal olarak da içinde yaşadığı topluma güven beslemesi ve sadakat göstermesi beklenmektedir. Bir başka deyişle siyasal topluma güven, bireyin mevcut hükümet kurumlanının ötesinde milletine olan sosyo-psikolojik bağlllı̆̆ın ve ülkesinin siyasal kaderine diğer vatandaşlarla birlikte ortak yön verme arzu ve istekliliğini anlatır (NORRIS, 1999: 10). Vatandaşların milletine siyasal bağlılığın ölçmeye yönelik sorulan iki soru ise şunlardır:

- Bir Türk olmaktan dolayı ne kadar gurur duyuyorsunuz? Seçenekler: (4) Çok gurur duyuyorum, (3) oldukça gurur duyuyorum, (2) pek gurur duymuyorum, (1) hiç gurur duymuyorum.

- Elbette hepimiz bir savas olmasın temenni etmiyoruz, ama eğer bir savaş olursa kendi ülken için savaşır mısın? Seçenekler: (1) Evet, (0) Hayır.

5.2. Demokratik rejime güven: Burada vurgulanması gereken vatandaşların sistemin değerlerini temsil eden siyasal ilkelere duyduğu güven ve sağladığı destektir. Bircylerin demokratik rejimi değerlendirebilmesi için aynı zamanda başka rejim tipleri hakkında da bilgi sahibi olmaları gerekir (KLINGEMANN, 1999). Bu amaçla sorulan iki soru aşağıdadır:

- Şimdi size değişik siyasal sistemleri anlatacağım ve ardından da bunların her birisi için bu ülkeyi yönetme biçimi olarak sizin ne düşündüğünüzü soraca-

1 Dünya Değerler Araştırmasının 1990-1991 döneminde gerçekleştirilen ilk ayağının genel sonuçlan için bakınız: Türk Toplumunun Değerleri, Istanbul, TÜSIAD, 1991. 1996-1997 döneminde gerçekleştirilen ikinci araştırmanın genel sonuçlan için bakınız:Yılmaz Esmer, Deorim, Eorim, Statüko: Türkiye'de Sosyal, Siyasal oe Ekonomik Değerler, Istanbul: TESEV Yayınlan, 1999. 
ğım. Her bir rejim için aşağıdakilerden hangisini söyleyebilirsiniz? Demokratik siyasal sistem bu ülkeyi yönetmek için (4) çok iyi, (3) oldukça iyi, (2) kötü, (1) çok kötü bir sistemdir.

- Demokratik siyasal sisteme ilişkin aşağıda verilen ifadelere katılip katılmadığını belirtiniz. "Demokratik sistemin bazı sorunları olabilir ama diğer her tür hükümet seklinden daha iyidir" ifadesine (4) kesinlikle katıliyorum, (3) katıliyorum, (2) katılmiyorum, (1) kesinlikle katılmiyorum.

5.3. Hükümetin performansına ilişkin destek: Burada kastedilen vatandaşların ülkedeki mevcut siyasal sistemin işleyişi ile ilgili değerlendirmeleridir. Bu amaçla sorulan sorular şunlardır:

- Iktidarda bulunan kişilerin ülkenin işlerini yönetme biçiminden ne kadar memnunsunuz? Seçenekler: (4) Çok memnunum, (3) oldukça memnunum, (2) pek memnun değilim (1)hiç memnunum değilim.

- Bu ülkenin yönetim sistemine ilişkin herkesin farkl görüşü var. Size bu ülkede işlerin nasil gittiğini belirten bir ölçek göstereceğim (1 çok kötü ve 10 çok iyi demektir).

- Bugünkü mevcut siyasal sistemi bu ölçeğe göre nasıl değerlendirirsiniz?

- On yll önce yıl öncesindeki siyasal sistemi nassl değerlendirirsiniz?

- Size bazı kurumların adını söyleyeceğim. Bu kurumlardan her birisine ne kadar güvendiğinizi söyleyiniz. Seçenekler: (4)Çok güvenirim, (3)oldukşa güvenirim, (2)Pek güvenmem, (1)Hį̧ güvenmem.

- Ankara'da iş başında bulunan hükümet

- Meclis

- Mahkemeler

- Memurlar

Tablo 1'de sunulan veriler Türkiye'de halkın içinde yaşadığı siyasal topluma, siyasal sisteme ve kurumlara yönelik değerlendirmesi hakkındaki genel bulguları göstermektedir. Ayrıntılar incelendiğinde görülmektedir ki vatandaşlar kavramsal olarak zihinlerinde üç çeşit siyasal güven düzeyini ayırt edebilmektedirler. Demek ki vatandaşlar siyasal toplumu hükümet şeklinden ve kurumlann performansından bağımsız olarak düşünüp değerlendirebilmektedir. Iş başındaki hükümete güvensizlik duyarken demokratik siyasal sistemi kuvvetle destekleyebiliyorlar. Ayrıca, Türk halkınun sistemle ilgili değerlendirmesini hiyerarşik olarak üç gruba ayrrabiliriz. Öncelikle, Türkler çok büyük oranda kendi milletiyle gurur duymakta (\%94) ve kendi ülkesi için savaşmaya hazır olduğunu (\%96) belirtmektedirler. Yine Türk halkının yüzde 85'i 
Birol Akglia • Turkiye'de Siyasal Goven: Nedenleri ve Sonuçları • 9

Tablo 1: Türkiye'de Siyasal Güvenin Boyutlan

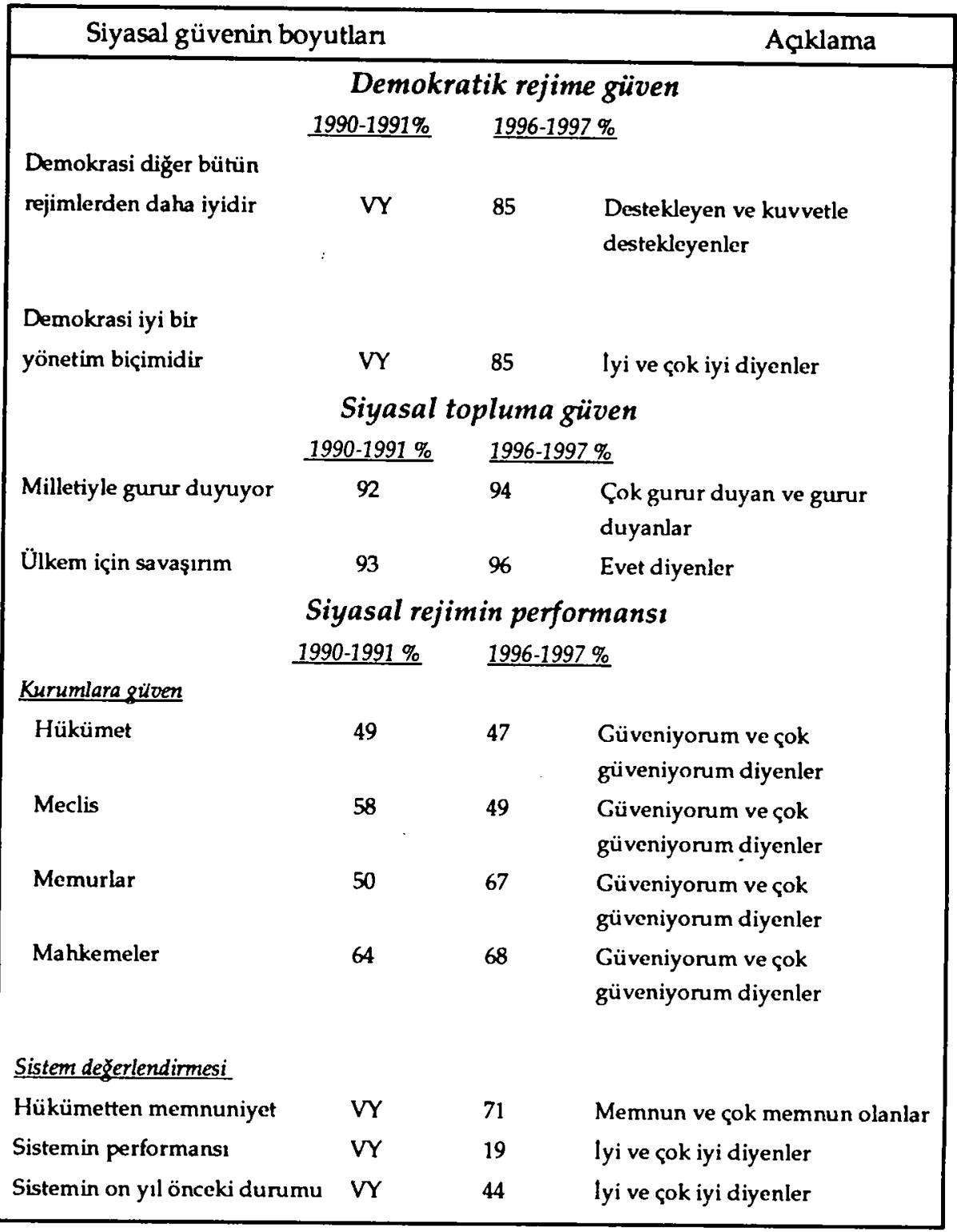

Not: VY: Veri yok. Bazı sorular 1990-1991 araştımasında sorulmamıştır. Bu soruların tam metni ve kodlanmast ekte sunulmustur. $N=1030$ (1990-91), $N=1907$ (1996-97) Michigan.

Kaynak: World Values Suroey 1995-1997 (Dünya Değerler Araştırması), University of 
demokratik siyasal rejimin diğer bütün rejim tiplerinden daha iyi bir yönetim biçimi olduğuna inanmaktadır. Fakat, halkın iş başındaki hükümetin ve diğer siyasal kurumların performansını değerlendirilmesi istendiğinde ise bu kadar yüksek bir destekten söz etmek mümkün değildir. Her ne kadar vatandaşlann çoğunluğu mahkemelere ve bürokrasiye güven duymaktaysa da demokratik siyasasal sistemin iki çok önemli kurumu olan meclise ve hükümete güven diğer kurumlara göre oldukça düşüktür.

Değerlendirmelerin ve güvenin zaman içindeki değişim trendini incelemek ise daha yararh olacaktır. Her ne kadar bazı sorular birinci araşturmada sorulmadığı için verilerde eksiklik varsa da en azından kurumlar ve hükümete güven düzeylerini karşılaştırma imkanuna sahibiz. Tablo 1'de güven düzeyinde meydana gelen değişikliğin tek yönlü olmadığı, bazı kurumlara güven artarken diğer bazı kurumlara güvenin azaldığı görülmektedir. Örneğin, siyasal topluma olan güven ve destekte hafif bir artıs görülürken bazı anahtar kurumlar (hükümet ve meclis) güven kaybına uğramıs gözükmektedir. Gene bir bütün olarak sistemin işleyişi on yll öncesine göre daha düşük bir performans gösterdiğine inanulmaktadır, olumlu görenler yüzde 44'ten yüzde 19'a düşmüştür. Bu sonuç ise hem sistemin meşruluğunu ilgilendirdiği için hem de ülkede etkili siyasal karar alma mekanizmaların zayıflatacak bir gelişme olduğu için ciddiyete alınması gereken bir durumdur.

Bu sonuçlar hem anlaml hem de başka araştırmacıların bulgularıyla tutarlıdır (bkz. NORRIS, 1999). Sonuçlar bize göstermektedir ki Türk halkında demokrasinin gerçek hayatta işleyişine ilişkin bir memnuniyetsizlik gözlenirken demokrasinin diğer yönetim şekilleriyle karşılaştırıldığında en iyi yönetim şekli olduğu kanaati halkın çok büyük çoğunluğunca paylaşılmaktadır. Klingemann'ın (1999) deyişiyle bu kişileri "kızgın demokratlar" olarak nitelemek mümkündür. Özbudun'un da belirttiği gibi ülkemiz demokrasisinin 1970'lerden beri sergilediği düşük performansa rağmen hem elit düzeyinde hem de halk arasinda demokratik siyasal rejime güçlü bir bağhlığın oluştuğu gözlemlenmektedir (ÖZBUDUN, 1996).

\section{Siyasal Güveni Etkileyen Faktōrler}

Şu ana kadar sunulan veriler bize Türkiye'de demokratik siyasal rejimin bir yönetim biçimi olarak halk tarafından içtenlikle desteklenip sahip çıkıldığını buna karşın siyasal sistemin performansının ise halkın çoğunluğu tarafından yetersiz bulunduğunu göstermektedir. Peki vatandaşların siyasal sistemin işleyişine ve temel kurumlanna ilişkin duyduğu güvensizlik nasıl açlklanabilir ve hangi faktörlerden etkilenmektedir?

Bu çalışma bağımlı değişken olarak bir "güven indeksi" kullanmaktadır. $\mathrm{Bu}$ indeks halkın meclise, hükümete, mahkemelere ve memurlara güvenini 
ölçen dört ayn değişkenden oluşturulmuştur. Bu güven indeksinin değerleri 4 (en yüksek güveni gösterir) ve larasında değişmektedir.

Bu indeks, vatandaşların hükümete ve kurumlara yönelik genel güvenini göstermekte olup çalışmamızda bağımlı değişkeni temsil etmektedir. Indeks değerlerinin dağlımı bize halk arasında siyasal kurumlara güvenenlerden çok güvenmeyenlerin çoğunlukta olduğunu, yani hoşnutsuzluğun yaygın olduğunu göstermektedir. Indeks skorlarının dağılımı aşağıdaki gibidir. Siyasal kurumlara "çok güvenenler" (4) ve "güvenenler" (3) sırasıyla yüzde 19 ve 22 'dir. Güvenmeyenler ise sayıca çoğunlukta olup "güvenmeyenler" (2) ve "hiç güvenmeyenler" (1) siraslyla yüzde 22 ve 38 'dir.

Hemen akla gelen soru değişik partilerin seçmenleri arasında güven düzeyi bakımından fark olup olmadığıdır. Özellikle iktidarda bulunan partilerin seçmenleriyle muhalefette bulunan partilerin seçmenlerinin sisteme güven bakımından farklı tutumlara sahip olabileceği beklenmelidir. Nitekim bazı yazarlar (MILLER/LISTAHUG, 1990) iktidarda bulunan parti (ya da partilerin) seçmenleri arasında siyasal sisteme güvenin yüksek olacağın, çünkü bu seçmenlerin kendi çkarlarının ve değerlerinin hükümetçe temsil edildiği duygusuna sahip olmaları gerektiğini savunur. Acaba Türkiye için böyle bir durum var midir?

Tablo 2'de sunulan bulgular bu tezi desteklemektedir. Iktidar partilerini destekleyen seçmenlerin ortalama güven indeksi değerlerinin muhalefet partilerini destekleyenlere göre oldukça yüksek olduğu görülmektedir. Örneğin, 1990-91 araştırmasına göre iktidar partisi ANAP'ı destekleyen seçmenlerin ortalama güven indeksi değeri 2.96 'lk bir skorla en yüksekteyken, bu değcrin 1997 yılında oldukça düşmüş olduğu görülür. Bunun aksine birinci araştırmada en düşük güven duyan parti seçmenleri DYP ve RP olurken, 1997 yllındaki araştırmada bu iki partinin üyelerine ait indeks değerleri en yüksek orandadır, çünkü arhk her iki parti de bir koalisyon hükümetinde (Refahyol) iktidardadırlar. Gene tablonun alt kısmında yer alan ve iş başındaki hükümetin performansından memnuniyeti gösteren değerlere bakıldığında da benzer durum söz konusudur. Ortalama olarak en çok memnun olduğunu belirtenler iktidar partisinin destekçileridir (RP 2.75 ve DYP 2.44). Demek ki kendi partisi iktidarda olan vatandaşlar siyasal kurumları ve hükümetin işleyişini daha olumlu görme eğilimindedirler. Bunun nedeni de demokratik siyasal sistemin vatandaşlara memnun olmadıklan iktidan seçimler yoluyla barış̧ıl biçimde değiştirebilme fırsatın vermiş olmasıdır. 
Tablo 2: Parti Tercihi, Kurumlara Güven ve Hükümetin Performansindan Memnunluk

\begin{tabular}{|c|c|c|c|c|c|}
\hline \multicolumn{6}{|c|}{ Ortalama Güven Indeksi Değerleri } \\
\hline \multirow{2}{*}{$\frac{\text { Parti tercihi }}{\text { ANAP* }^{*}}$} & \multicolumn{2}{|c|}{$1990-1991(N=1030)$} & \multicolumn{2}{|c|}{$1996-1997(N=1907)$} & \multirow{2}{*}{$\frac{\text { Fark }}{-.23}$} \\
\hline & 2.96 & $(n=217)$ & 2.73 & $(n=188)$ & \\
\hline CHP & 2.43 & $(n=191)$ & 2.45 & $(n=162)$ & +.02 \\
\hline DSP & 2.79 & $(n=133)$ & 2.37 & $(n=184)$ & -.42 \\
\hline DYP** & 2.27 & $(n=121)$ & 2.85 & $(n=1164)$ & +.58 \\
\hline $\mathrm{RP}^{* *}$ & 2.28 & $(n=43)$ & 2.80 & $(n=222)$ & +.52 \\
\hline MHP & 2.37 & $(n=15)$ & 2.65 & $(n=102)$ & +.28 \\
\hline \multicolumn{6}{|c|}{ Parti tercihi ve hükümetin performansindan memnuniyet (1996-1997) } \\
\hline & ANAP & & 1.98 & $(n=186)$ & \\
\hline & $\mathrm{CHP}$ & & 1.73 & $(n=162)$ & \\
\hline & DSP & & 1.66 & $(n=183)$ & \\
\hline & DYP** & & 2.44 & $(n=158)$ & \\
\hline & $\mathrm{RP}^{* *}$ & & 2.75 & $(n=220)$ & \\
\hline & MHP & & 1.96 & $(n=102)$ & \\
\hline
\end{tabular}

Not: Sadece büyük partilerin seçmenlerine ilişkin değerler sunulmuştur.

*: 1990-91 araştımast strasında iktidar partisidir.

**: 1996-1997 araştırmastnda koalisyon ortaklardır.

Buradaki güven indeksi dört sorunun verilerinden hesaplanmıstır, bunlar hükümete, meclise, mahkemelere ve memurlara yönelik güveni ölçen sorulardan oluşur. Hükümetten memnuniyet ise halkın iş başındaki hükümet in performansından ne kadar tatmin olduklarını gösterir. En yüksek memnuniyet 4 ile en düşük ise 1 ile gösterilmiştir.

Kaynak: World Values Suroeys 1990 oe 1997, University of Michigan.

Elbette ki kişilerin oy verdiği partinin iktidara gelmiş olması insanların sisteme güvenini artıracaktır ama bunun yanında başka diğer faktörler de bireylerin siyasal kurumlara yönelik güvenini ya da güvensizliğini etkilemektedir. Biz, çalışmamızın bu aşamasında, halkın hükümete ve siyasal kurumlara güvensizliğini ve memnuniyetsizliğini etkileyen ve yukarıda tartışılan iki yaklaşımı, (aşır talep artışı ve yönetim sürecindeki adaletsizlikler), çok değişkenli 
regresyon tekniğini yöntemini kụllanarak test edeceğiz. Analizde kullanulan ve bireylerin hükümetin performaṇsına ilişkin değerlendirmelerini, deneklerin siyasal ilgi düzeylerini, ideoloji ve gelir düzeylerini gösteren değişkenler benzer çalışmalarda ve diğer kamuoyı araştırmalarında yaygın olarak kullanulan değişkenlerdir (CRAIG/MAGGI()TTA, 1982; WEATHERFORD, 1987). Bunların nasıl kodlandığı ek 1'de sunulmuştur. Şu kadarın belirtmek gerekir ki bağımsız değişkenler arasında bulunan en yüksek korelasyon katsayısı "cinsiyet" ile "dinsellik" arasında gözlemlenmiş olup Pearson (r) değeri .421'dir.

\section{Hipotezler}

Bu çalışmada, bağımsız değişkenlerle ile siyasal kurumlara güven arasında aşağıdaki ilişkilerin olacăğı beklenmektedir:

Hipotez 1: Aşııı talep arțşı yaklaşımının söylediği gibi, hükümetin iş başarma kabiliyeti ve yönetimdeki etkinilği arttkça vatandaşların dẹsteği ve güveni de artacaktır.

Hipotez 2: Siyasal süreç yaklaşımınn öne sürdüğü gibi, bireylerin siyasal sürecin adil işlediği ve halkın arzularına duyarlı olduğuna ilişkin inançları ne kadar artarsa siyasal kurumların işleyişinden memnuniyetleri de o derce artacaktor.

Hipotez 3: Bireylerin siyasăl olaylara ilgi düzeyi yükseldikçe hükümete güvenlerinin azalması ve hoşnutsuzluklanın artması beklenmelidir.

\section{Bulgular ve Analiz}

1990-91 yulında yapılan ilk araştırmada bazı verilerin eksik olması nedeniyle halkın hükümete güvenini etkileyen faktörleri açklamak için kullanılan çok değişkenli regrasyon analizinde sadece 1997 verileri kullanılmıştır. Elde edilen sonuçlar tablo 3 'te sunulmuştur. Burada kullanulan bağımlı değişken yani açıklanmaya çalışılan şey siyasal kurumlara güvendir ki bu dört değişkenden oluşmuş bir güven indeksidir.

Türkiye'de siyasal güveni etkileyen faktörleri açıklayan yukarıdaki tabloda modelin açıklama gücü $.230^{\circ}$ dur, yani kullanılan veriler bağımlı değişken olarak tanımlanan halkın hükümet kurumlarına güveninin yüzde 23'ünü açklamaktadır. Peki güvenị en çok hangi faktörler etkilemektedir? Bunu anlamak için model içinde hangi değişkenin tahmin katsayısının daha yüksek olduğuna bakmak gerekir. Kurulan modelde en güçlü açiklayıcı değişken (üçüncü sütundaki Beta değerlerine bakınız) vatandaşların hükümetin performansından ne kadar memịun olup olmadığın gösteren değişkendir. 
Görüldüğü gibi bu değişkenin işareti andır ki bu da vatandaşların iş başında bulunan iktidarın performansından memnuniyetleri arttkça genel olarak siyasal kurumlara güvenlerinin de arttğını göstermektedir. Bu sonuç bize hükümetin iş başarma kabiliyeti ve yönetimdeki etkinliğinin vatandaşların siyasal kurumlara yönelik tutumlann pozitif yönde etkilediğini göstermektedir ki bu da yukarnda öngörülen birinci hipotezi doğrular niteliktedir.

Tablo 3: Türkiye'de Siyasal Güveni Etkileyen Faktörler

\begin{tabular}{|c|c|c|c|c|}
\hline Bağımsız Değişkenler & $\begin{array}{l}\text { Eğim } \\
\text { Katsayısı }\end{array}$ & $\begin{array}{c}\text { Standart } \\
\text { Hata }\end{array}$ & $\begin{array}{c}\text { Beta } \\
\text { Değerleri }\end{array}$ & $\begin{array}{l}\text { Yanılma } \\
\text { Payı }\end{array}$ \\
\hline Sabit & 2.263 & .110 & & .000 \\
\hline $\begin{array}{l}\text { Hükümetin performansından } \\
\text { memnuniyet }\end{array}$ & .268 & .026 & .303 & .000 \\
\hline Siyasal ilgi düzeyi & $-.9 .36 \mathrm{E}-02$ & .029 & -.85 & .001 \\
\hline $\begin{array}{l}\text { Ülkenin büyük çıkar } \\
\text { gruplarınca yönetildiğine } \\
\text { yönelik inaņ̧ }\end{array}$ & -.165 & .051 & -.090 & .001 \\
\hline Ideoloji (sağci-solcu) & $1.80 \mathrm{E}-02$ & .008 & .064 & .023 \\
\hline Dine bağhlık & $3.259 \mathrm{E}-02$ & .009 & .109 & .001 \\
\hline Cinsiyet $(E=1, K=0)$ & -.171 & .040 & -.117 & .000 \\
\hline Gelir Düzeyi & $-2.35 \mathrm{E}-02$ & .008 & -.078 & .004 \\
\hline $\mathbf{R} 2$ & .230 & & & \\
\hline Standart tahmin hatası & .637 & & & \\
\hline
\end{tabular}

Not: Bağımlı değişken kurumlara güven indeksidir (hükümete, meclise, mahkemelere memurlara güoen). Bu indeksteki değerler en yüksek güveni temsil eden 4 ve en düşük gü̃oni gösteren 1 arasında değişmektedir (Alpha $=.740$ ).

Kaynak: World Values Suroey, 1995-97.

Diğer değişkenlerle karşılaştırıldığında ikinci açıklayıcı güce sahip faktör ise cinsiyettir. Işaretinin eksi olması ankete kathlan dencklerden bayanların erkeklere göre daha şüpheci, başka deyişle siyasal kurumlara daha az güvendikleri anlaşlmaktadır. Üçüncü sırada ise dine bağlılık gelmektedir. Bireylerin dine bağlılıkları arttıkça genel olarak siyasal kurumlara güven duygularınun da yükseldiği anlaşılmaktadır. Bu sonucu nasıl açıklamak gerekir? Bunun bir yorumu şu olabilir. Bireylerdeki dini inançlarıyla otoriteye saygı arasında bir ilişkinin var olduğu iddia edilebilir. Siyasal kurumların da otoriteyi temsil ettikleri düşünülürse bireylerdeki otoriteye yönèIlk olumlu tutumların 
siyasal kurumlara da yansıdığı söylenebilir. Bir başka yaklaşım da şu olabilir. Dinine bağlı bireylerin dini törenlere ve toplantulara daha sık gittiği göz önünde tutulursa bu aktivitelerin bir çeşit sosyal kathlımın ve etkileşimin bir ölçüsü olarak alınabilir. Putnam'ın da belirttiği gibi bireylerin sivil ve sosyal aktivitelere katılmaları kişilerin kendi toplumuna ve kurumlarına olan inancan ve güvenini arturmaktadır (PUTNAM, 1993 ve 1995).

Siyasal kurumlara güveni etkileyen ikinci gruptaki faktörler ise ülkenin büyük çkar gruplannca yönetilựiğine yönelik inaņ̧ ve bireylerin siyasal ilgi düzeyleridir. Daha çok ülkenin yönetim sürecinde haksızlıklar olduğu (rüşvet ve yolsuzluklar) ve sıradan kişilerin karar alma sürecini ve günlük politik olaylan etkilemede katkısının olmadığı yönündeki bir inancı yansitan bu yargı insanları ümitsizliğe ve güvensizliğe ittiği anlaşılmaktadır ki bu da ikinci hipotezimizi destekleyen bir bulgudur. Öte yandan bireylerin siyasete ilgi düzeyleri ile hükümet kuruluşlarına güvenleri arasında da negatif bir ilişkinin olduğu görülmektedir. Kavram olarak "siyasal ilgi" kişilerin siyasal olaylan kendi aralarında sıklıkla tartışmalan olarak tanımlanır. Doğaldır ki sık sık siyaset tartışan kişiler ülkede siyasal kurumların nasıl işlediğine ilişkin daha derin bilgi sahibi olurlar. Bunun sonucunda da siyasal ilgi düzeyleri yüksek bireyler hükümette ve kurumlarda görülen yozlaşma, rüşvet ve haksızlıklara karşı daha duyarlı hale gelirler ve yönetim sürecinden hoşnutsuzluklan artar. Bu bulgu da üçüncü hipotezimizi desteklemektedir.

Daha az önemdeki diğer iki değişken ise ideoloji ve gelir düzeyidir. Ideoloji değişkeninin işaretinden Türkiye'de kendini sağcı olarak tanımlayanların siyasal kurumlara olan güveninin solculara göre daha yüksek olduğunu göstermektedir. Başka bir deyişle solcuların daha şüpheci ve sorgulayıcı oldukları ortaya çıkmaktadır. Ayrıca araştırmanın yapıldığı tarihte iki sağ partinin (Refahyol) kurduğu hükümetin iş başında bulunması da böyle bir sonucu doğurmuş olması düşünülebilir. Bir başka ilginç sonuç da bireylerin gelir düzeyleri ile siyasal güvenin|ters orantilı olmasıdır. Başka deyişle, nispeten zengin olanlar fakir olanlara görẹ hükümet kurumlarına karşı daha az güven duymaktadırlar. Bunu nasıl açıklayabiliriz?

Öncelikle Türkiye gibi gẹlişmekte olan ülkelerdeki sosyo-ekonomik gelişmenin yapısınun bilinmesi gejeklidir. Ekonomik alandaki dalgalanmalar ve krizler kentlerde yaşayan modernleşmiş orta sınffı daha çok ve doğrudan etkilerken geçimini tarım ve hayvanalıktan sağlayan kırsal kesimde yaşayan kitleleri daha az etkiliyor olabilir. Türkiye'de görece daha zengin gruplarn şehirlerde yoğunlaştğ̆ dikkate |alınırsa ani çıkan krizler ve ekonomideki dalgalanmaların (örneğin enflasyon) bu kesimin gelir düzeyini doğrudan etkilediği düşünülebilir. Diğer yandan kırsal nüfusun gelir kaybın bir şekilde telafi etme imkanı varken (aile içi yardımlaşma, geçimlik tarım gibi) bordroya bağlı şehirli işçi ve memur kesiminin gelir azalmasına karşı daha duyarlı olduğu 
savunulabilir. Nitekim gelişmekte olan ülke seçmenleri üzerinde yapulan bir incelemede şehirlerde yaşayan modern sosyal kesimlerin ekonomik trendlere karşı kırsal nüfusa göre daha duyarlı olduğu bulunmuştur (PACEK VE RADCLIFF, 1995). Öte yandan yüksek gelirlilerin düşük gelirillere göre siyasal kurumlara daha az güvendiği olgusu Türkiye'ye özgü bir durumda değildir. Amerika'daki seçmen araşturmalarında ortalama geliri 5000 dolardan az olanlann ortalama geliri 15000 dolardan çok olanlara göre siyasal kurumlara daha çok güvendikleri, ama bu durumun daha sonraları tersine döndüğü ortaya konmuştur (CITRIN, 1974).

\section{Siyasal Güvenin Siyasal Davranışa Etkileri}

Siyaset bilimciler siyasal güven düzeyi ile siyasete kathlım ve oy verme davranışı arasında bazı ilişkilerin bulunabileceğini söylemişlerdir. Bazı yazarlar hükümetin performansından memnun olmayanların protesto partilerine ya da aşırı sağd partilere oy vermeye daha yatkın olduklanın iddia etmektedirler. Örneğin Miller ve Listhaug (1990) Norveç'tcki protesto hareketini temsil eden popülist bir sağ partiye oy verenlerin genel siyasal güven duygularının diğer partilerin seçmenlerine göre çok daha düşük olduğunu göstermiştir. Öte yandan Teixeira (1992) demokrasinin yerleştiği ileri sanayi ülkelerinde sisteme yönelik artan şüpheciliğin seçmenlerin oy vermeye gitmeme ve siyasete katılmama şeklinde etkisini gösterdiğini söylemektedir. Biz de yukarıdaki önermelerden yola çkarak Türkiye'de siyasal güvensizlik ile seçmenlerin siyasal davranı̧ları arasında ne tür bir ilişki olabileceğine bakacağız.

Türkiye'deki yaygın bir yaklaşım Milliyetçi Hareket Partisinin (MHP) ve Fazilet Partisinin (FP) siyaset yelpazesinin en sağında yer aldığı ve ilkinin milliyetçiliği ikincisinin de dini değerleri temsil ettiğini kabul eder. Bazı çalışmalar bu iki partinin artan oy oranlarının nedenini seçmenler arasında yükselen karamsarlık ve artan güvensizlikten kaynaklanan protesto oylarınun bu iki partiye yönelmesiyle açiklamaktadırlar (ÖNIŞ, 1997; YAVUZ, 1997; ÖZBUDUN, 1996; AKGÜN, 1999). Acaba gerçekten de bu iki partinin oy tabanlanı oluşturan seçmenler diğer seçmenlere göre siyasal güven düzeyi bakımindan farklı midırlar?

Sekil 1siyasal kurumlara güven düzeyi ile protesto partileri diye adlandınlan (MHP ve FP) partilere yönelik destek arasındaki ilişkiyi göstermektedir. Ortaya çıkan sonuç Miller ve Listhaug'un aşın sağ partilerin sisteme güvensizlik duyan seçmenlerden daha ziyade oy aldığı iddiasını destekler mahiyettedir. Sisteme güven indeksi 4 olan seçmenler arasında bu iki partiye oy verecekler sadece yüzde 13 'te kalırken, güven düzeyi en düşük olanlar (indeks değeri 1) arasında bu iki partinin toplam desteği yüzde 44 'ü bulmaktadır. Bunun aksine sisteme en çok güvenen seçmenler ya hiç oylamaya 

1

Sekil 1: Türkiye'de Siyasal Güven ve Aşırı Sağ Partilere Destek

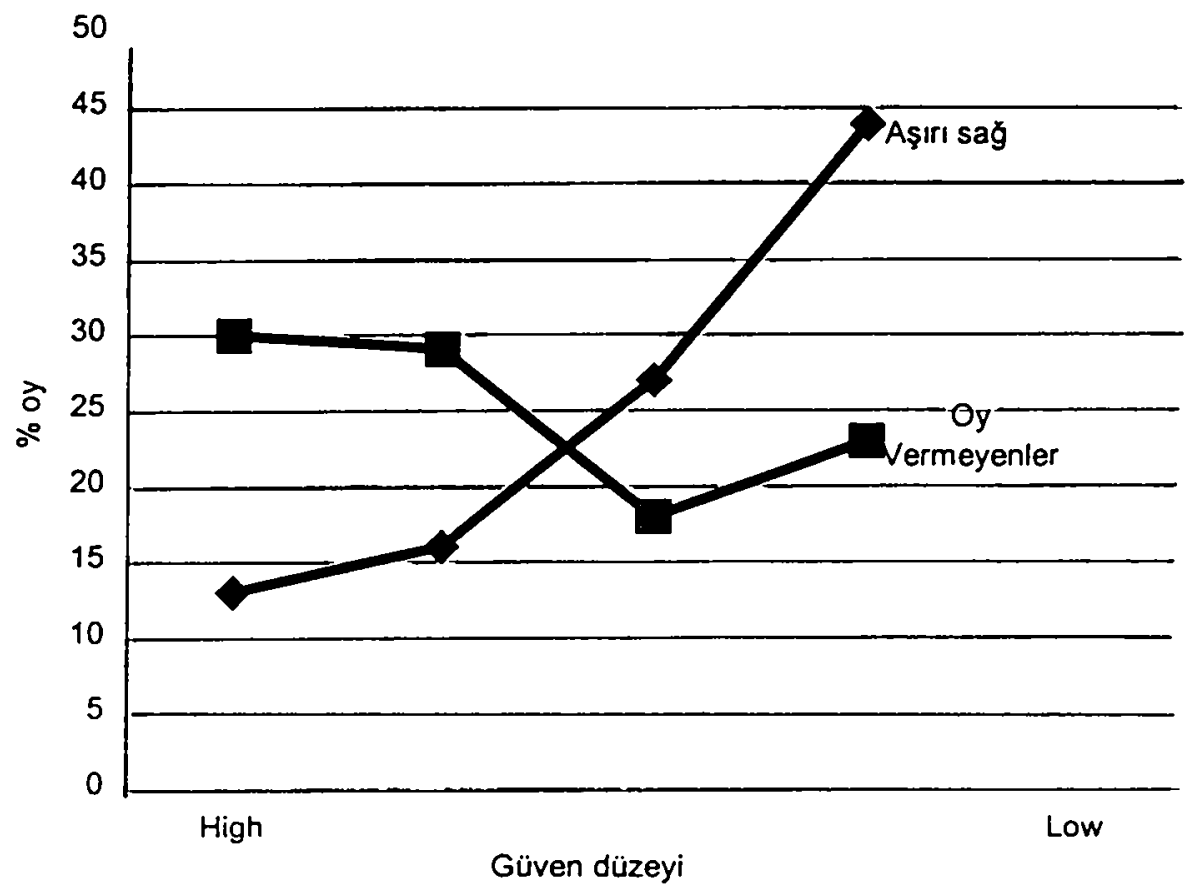

katılmama ya da sol partilere oy verme seklinde kendini göstermektedir. Oylamaya kathlmayacağını belirtenlerin ortalama güven düzeyi 2.65'tir. Demek ki seçimlerde oy vermeye gitmeyeceğini belirtenler genellikle ülkedeki gidişattan memnun olanlardır, siyasete yabanclaştıklan ya da kendi öz güvenlerini kaybettikleri için değil.

\section{Tartışma ve Sonuç}

Demokratik siyasal sistemi diğer siyasal rejimlerden aynlan en önemli özellik meşruiyetini halk egemenliğinden almış olmasıdır. Yönetenler yönetilenlerin oyuyla işbaşına gelirler ve ancak onların rızası, onayı ve güveni devam ettiği sürece iktidarda kalabilirler. Halkın tercihleri ise seçimler yoluyla siyasete yansır. Toplumsal, ekonomik ve siyasal alanda başarısızlik gösteren partiler zor kullanılmadan barış̧̧ yollarla işbaşından uzaklaştırlabilirler. Eğer iktidara getirilen değişik partiler aynı sorunları çözmede sürekli yetersiz kalırlarsa geniş halk kesimlerinde demokrasinin işlemediği, sistemin tıkandı̆̆ı gibi kanaatler yayilmaya başlar (MILLER/LISTHAUG, 1990). Sonuçta da seçmenlerin sisteme yönelik güvenleri azalır ve rejimin meşruluk temeli 
zayıflamaya başlar ki bu durum da siyasal istikrarsızlıklara, krizlere ve hatta özgürlükçü demokrasinin tamamen ortadan kalkmasına ya da kısmen askıya alınmasına yol açabilir. Onun için demokrasi teorisyenleri hemen her ülkede güven erozyonunu rejim için ciddiye alınması gereken bir alarm olarak değerlendirirler.

Bu analizimizde biz de ülkemizde halkın rejime ve kurumlara güvenini incelemeye çalıştık. Bazı sonuçlar demokratik siyasal sistemin devamı için ümit verici iken bazı sonuçlar ise krizin ip uçların vermektedir. Her şeyden önce ülkemizdeki insanların ortak yaşama arzusunu ve siyasi olarak birlikte var olma iradesini yansıtan siyasal topluma güven ve gerektiğinde bu ülke için savaşma arzusu vatandaşların yüzde 95 gibi çok büyük bir çoğunluğu tarafından paylaşılmaktadır. En az bunun kadar önemli bir bulgu ise halkın yüzde $85^{\prime}$ inin demokrasiye güvenmesi ve demokratik siyasal rejimi en iyi yönetim şekli olarak görmeleridir. Ancak bireylerin hükümet, meclis, bürokrasi gibi siyasal kurumlara güveninde ciddi bir düşüs olduğu gözlenmektedir. Bu ise uzun dönemde siyasal ve toplumsal hayatımızı istikrarsızlaştırma potansiyeli taşımaktadır.

Istatistiki verilerin analizinden ortaya çıkan sonuç göstermektedir $\mathbf{k i}$ Türkiye'de siyasal güvensizliğin en önemli nedeni halkın, bir bütün olarak siyasal kurumların performansın yetersiz bulmalarıdır. Diğer önemli bir neden de vatandaşların, yönetim sürecinde yaygın adaletsizlikler ve haksızlıklar (rüşvet, adam kayırma, yolsuzluk vs) olduğu inancından kaynaklanmaktadır. Yönetimin büyük çıkar gruplarının etkisi altında olduğu, sıradan vatandaşların etkisinin sınurl kaldığı yönündeki kanaatler bircylerin sisteme olan güvenini aşındırmaktadır. Bunun sonucu olarak kendilerini halkın gerçek temsilcisi, siyasetteki sesi olarak tanitan popülist protesto partilerinin gelecekten ümitsiz, kendisini dışlanmış hisseden seçmen kitlelerinden artan oranda oy topladıklanı gözlemlenmektedir. Nitekim son on yllda merkez sağ ve merkez sol sürekli oy kaybederken yakın zamana kadar marjinal sayılan bazı partiler mecliste ağırlıklı olarak temsil edilme imkanı bulmuşlardır. Elbette ki bu partiler de anayasal sinurlarda faaliyet göstermektedirler ve oy desteği oranunda siyasal iktidardan pay alma haklann sonuna kadar kullanacaklaradır. Ancak Refahyol döneminde yaşananlar göz önüne alındığında bu partilerin iktidara ortak olduklarında sistemde bazı gerginlikler yarattkları da yadsınamaz bir gerçektir.

Son olarak bizim analizimiz 1997 'de toplanan verilere dayanmaktadır. Son bir kaç yılda yaşanan siyasal ve ekonomik gelişmeler toplumla siyasal kurumlar arasındaki güven bunalımını daha da derinleştirdiği açktır. Geçmişinde demokrasi açısından acı tecrübeler bulunan ülkemizde son yllarda belirgin hale gelen güven kaybı ciddiye alınması ve nedenleri araştırılması gereken bir olaydır. Özellikle süre giden ekonomik krizler hem hükümete hem de genel olarak siyasal kurumlara (meclis, siyasi partiler, bürokrasi) yönelik güveni 
gittikçe aşındırmaktadır. Ülkemizde 17 Ağustos 1999 depreminin hemen ertesinde devletin bütün kurumlanyla müdahalede yetersiz kaldığı görüntüsü vermesi, siyasetteki tikanma, meclisin aşırı parçalı yapısı ve nihayet Kasım 2000 ve Şubat 2001 ekonomik krizleri halkın hükümete ve diğer kurumlara yönelik güvenini derinden sarsmı̧ gözükmektedir. Nitekim son zamanlarda yapılan anketler bunu açıkça göstermektedir. Örneğin Strateji Mori'nin Nisan 2001 tarihli anketinde vatandaşlara "önümüzdeki bir yl içerisinde ülkedeki sosyal koşullann nasıl olacağı" sorulduğunda deneklerin sadece yüzde 1.3'ü çok iyi olacak derken, yüzde 34'ü çok kötü olacak şeklinde cevaplamuştır. ANAR'ın yaptığı Mayıs 2001 tarihli bir diğer araştırmaya göre ise yıl başından bu yana iktidar partilerinin toplam oy oranı yüzde 21 'den yüzde 13.4 'e düşerken, ayn dönemde muhalefet partilerinin toplam oy aran ise artmamıs tam aksine yüzde 36 'dan yüzde 34.5 'e gerilemiştir. Demek ki seçmenler hem hükümetten hem de alternatif olabilecek diğer partilerden ümidini yitirmiş, onlara güvenini kaybetmiştir. En büyük grubu ise yüzde 38 ile hiçbir partiyi desteklemeyenler oluşturmaktadır. Eğer bu sonuçlar bir göstergeyse yapılacak yeni bir seçimde de hiçbir parti tek başına iktidara gelme imkanı bulamayacak demektir.

Sonuç olarak Türkiye'de siyaset yapanlar yukarıdaki verileri göz önüne alarak halkın taleplerine daha duyarlı olmaya özen gösterirken geniş kesimlerce dile getirilen daha şeffaf ve daha katılımcı bir demokratik yapının kurulmasına yönelik reformlara da hiz vermeleri gerekir. Reform çağrılarını görmezden gelmek kaçınılmaz olarak güven bunalımını derinleştirecek ve hatta ara rejim türü yan demokratik hükümetlerin destek bulmasına zemin hazırlayacaktır.

\section{Kaynakça}

AKGON. Birol (1999), "Türk Seçmen Davranşının Ekonomj Polltik'ı Ozerine Bir Model Denemesl," Liberal Düsünce, 14/4:33-47.

ALMOND, Gabriel A. / VERBA, SIdney (1965), The Civic Culture (Boston: Lttle. Brown).

CITRIN. Jack (1974). "Comment: The Pointcal Relevance of Trust In Govemment," American Political Science Review, 68: 973.88.

CRAJG, Stephen C./ MAGGlOTTO, Micheel A. (1981), "Political Discontent and Politcal Action," Jumal of Politics, 43: 514-22.

CANDAR, Cengiz (1999). "Redefining Turkey's Political Center," Joumal of Democracy, 10/4: 129.141.

EASTON, Dovld (1965). A System Aralysis of Polilical Life (New York: John Vlley).

EASTON, David (1975), "A Re-assessment of the Concept of the Political Support." British Jumal Political Science, 5: 435-457.

FINIFTER, Ada W. (1970). "Dimensions of Political Allenation." American Palitical Science Review, 64/2: $389-410$.

HIBBING, John R./ THEISS-MORSE. Elizabeth (1995), Congress as Public Enemy: Public Autudes Toward American political Institutions (Cambridge: Cambrldge University Press). 
KINZER, Stephen (1999). 'The Turkish Quake's Secret Accomplice: Cornuption.' The New York Times. August 29.

KUNGEMANN, Hans-Dieter (1999), "Mapping Political Support In Advanced Industrial Democracies," NORRIS. Pippe (ed.), Critical Citizens: Global Suppon for Democratic Govemment (New York: Oxford University Press).

LAWRANCE, Robert (1997), "Is it Really Economy, stupid?," NYE, Joseph S. / ZELIKOW, Philip D. / KING, Davld C. (eds.). Why People Don't Trust Government (Combridge. MA: Harvard University Press).

UPSET, Symour M./ WILIAM Schneider (1987). The Confidence Gap: Business, Labor and Govemment in Public Mind (Baltimore, MD: Johns Hopkins University Press, Revised Edition).

MULER, Athur H. (1974). 'Political lssues and Trust in Govemment: 1964-1970,' American Political Science Review, 68: $989-1001$.

MILLER, Arthur H./ USTHAUG, Ole (1999), "Political Performance and Political Institutions," NORRIS, Pippo (ed.). Critical Citizens: Global Support for Democratic Govemment (New York: Oxford University Press).

MLLER, Arthur H. / USTHAUG, Ole (1990). 'Politicel Parties and Confidence in Govemment: A Comparison of Norway. Sweden and the United States," British Joumal of Political Science, 20/3: 357-386.

MULLER, Edword N. / JUKAM. Thomas O./ SELJGSON, Mitchell A. (1982), "Diffuse Political Support and Anti System Political Behavior. A Comparative Analysis," American Jumal of Political Science. 26/2: 240.264 .

NORRIS, Pippe (Ed.) (1999), Critical Citizens: Global Support for Democratic Govemment (New York: Oxford University Press).

NYE, Joseph S. / ZEUKOW. Philip D. / KING. David C. (eds.) (1997). Why People Don't Trust Govemment (Cambridge, MA: Harvard University Press).

ONIŞ. Zyya (1997). "The Political Economy of Islamic Resurgence In Turkey: the Rise of Welfare Party in Perspective," Third World Quarterly. 1874: 743-766.

ÖZBUDUN, Ergun (1996). "Turkey: How Far from Consolidation?." Joumal of Democracy. 7/3: 123-138

PACEK. A. RADCLIFF, B. (1995), 'The Political Economy of Competitive Elections in the Developing World," American Joumal of Political Science. 39/3: 745.55.

PUTMAM, Robert D. (1995), 'Bowling Alone: America's Declining Social Cpaital,' Joumal of Democracy. 6/1: 65-78.

PUTNAM, Robert D. (1993), Making Democracy Work (Princeton, NJ: Princeton University Press).

SAKAU OOGLU, Ömit C. (1997). "The Anotorny of the Turkish Military's Political Autonomy," Comparative Politics, Januory: $151-165$.

SALT, Jeremy (1999). "Turkey's Military Democracy." Current History, February. 72-78.

TEIXEIRA, Roy A. (1992). The Disappearing American Voter (Washington: The Brookings Institution).

WEATHERFORD, Stephen M. (1987), "How Does Govemment Performance Influence Political Support," Political Behavior, 9/1: 5.28.

YAvUZ, Hokan M. (1997), "Political Islam and the Welfare (Refah) Party in Turkey." Comparalive Politics. 30/1: 63.82 . 


\title{
EK 1: Dünya Değerler Araştırması, (1990-91 ve 1995-97)
}

\author{
Calışmada Kullanılan Verilerin Sorular ve Kodlamalan Aşağıdadır
}

Siyasal ilgi düzeyi: Arkadaşlannla bir araya geldiğinizde siyasi olaylan ne kadar sıklıkla tartışırsınız?

1 Sık sık tartışırız

2 Bazen tartışırız

3 Asla tartışmayız

9 Bilmiyor (veri yok olarak kodlandi)

(Analizde bu kodlamalar ters çevrilerek 3 en yüksek ilgi düzeyini ifade için kullanıldı)

İdeoloji: Insanlar politikadan konuşurken "sağ" ve "sol" sınıflandırması yaparlar. Genel olarak konuşursak, siz kendinizi aşağıdaki ölçekte nereye yerleştirirsiniz?

$\begin{array}{llllllllll}1 & 2 & 3 & 4 & 5 & 6 & 7 & 8 & 9 & 10\end{array}$

Sol

Săg

Bilmiyorum $=99$, Cevap yok $=98($ veri yok (missing))

Güvenle ilgili sorular: belirtiniz.

Lütfen şu karta bakın ve verilen kurumlardan hangisine ne kadar güvendiğinizi

$\begin{array}{lcccc}\text { Çok } & \begin{array}{c}\text { Oldukça } \\ \text { Güvenirim }\end{array} & \begin{array}{c}\text { Pek } \\ \text { Güvenirim }\end{array} & \begin{array}{c}\text { Hi̧̧ } \\ \text { Güvenmem }\end{array} & \begin{array}{l}\text { Güvenmem } \\ \text { Mahkemeler }\end{array} \\ \text { Hükümet } & 1 & 2 & 3 & 4 \\ \text { Meclis } & 1 & 2 & 3 & 4 \\ \text { Memurlar } & 1 & 2 & 3 & 4 \\ & 1 & 2 & 3 & 4\end{array}$

(Analizde bu kodlar tersine çevrilmiştir, 4 en yüksek güveni ifade ctmcktedir)

Demokrasiye güven: Şimdi size değişik siyasal sistemleri anlatacağım ve ardından da bunların her birisi için bu ülkeyi yönetme biçimi olarak sizin ne düşündüğünüzü soracağım. Her bir rejim için aşağıdakilerden hangisini söyleyebilirsiniz? Demokratik siyasal sistem bu ülkeyi yönetmek için:

Çokiyi Oldukça iyi Kötü Çok kötü Fikri yok

$\begin{array}{llllll}\text { Demokratik yönetim } & 1 & 2 & 3 & 4 & 9\end{array}$

(Analizde bu kodlar tersine çevrilmiştir, 4 çok iyi demektir, fikrim yok diyenler veri yok "missing" kodlandı). 
Siyasal sistemi değerlendirme (reyting): Bu ülkenin yönetim sistemine ilişkin olarak insanlann farklı görüşleri vardır. Bu ülkede işlerin nasıl yürüdüğünü aşağıdaki ölçeğe göre değerlendiriniz. 1 çok kötü ve 10 çok iyi demektir.

$\begin{array}{llllllllll}1 & 2 & 3 & 4 & 5 & 6 & 7 & 8 & 9 & 10\end{array}$

Çok iyi

Çok kötü

On yıl önce: Aynı ölçeğe göre sizce bu ülkede işler on yl önce nasıldı:

Hükümetin performansı: Iktidarda bulunan kişilerin ülkenin işlerini yönetme biçiminden ne kadar memnunsunuz?

1 Çok memnunum

2 Oldukça memnunum

3 Pek memnun değilim

4 Hiç memnun değilim

9 Bilmiyorum

(Analizde bu kodlar tersine çevrilmiştir, 4 çok memnunum demektir, bilmiyorum diyenler ise veri yok "missing" olarak kodland.

Bu ülkeyi kim yönetiyor: Genel olarak konuştuğumuzda bu ülkeyi kim yönetmektedir?

1 Büyük çıkar gruplannca yönetiliyor

2 Halk tarafından yönetiliyor

9 Bilmiyorum

(Analizde yeniden kodlama: $1=1,2=0,9=$ veri yok)

Dini törenlere katılma: Düğünler ve cenazeler dışında dini servislere ne kadar sıklıkla katılırsını??

1 Haftada birden çok

2 Haftada bir

3 Ayda bir

4 Bayramdan bayrama

5 Özel dini günlerde

6 Yilda bir kez

7 Daha az.

8 Hemen hemen hiç katılmam

(Analizde bu kodlar tersine çevrilmiştir, 8 en yüksek katılımı ifade eder)

Siyasal topluma bağlılık ve destek: Bir Türk olmaktan dolayı ne kadar gurur duyuyorsunuz? 
1 Çok gurur duyuyorum

2 Oldukça gurur duyuyorum

3 Pek gurur duymuyorum

4 Hiç gurur duymuyorum

(Analizde bu kodlar tersine çevrilmiştir, 4 en yüksek gurur duymayı ifade eder)

Ülkesi adına savą̧ma: Elbette hepimiz bir savaş oimasını temenni etmiyoruz, ama eğer bir savaş olursa kendi ülken için savaşır mısın?

1 Evet

0 Hayır

Cinsiyet: Ankete katılan kişinin cinsiyeti

1 Erkek

2 Kadın

(Analizde erkek 1 olarak, kadınlar ise 0 olarak değiştirilmiştir)

Yaş: AGE: Ankete katılan kişinin gerçek yaşı.

Eğitim düzeyi: Ankete katılan kişinin eğitim düzeyi

1 Resmi eğitim kurumlanna hiç devam etmeyenler

2 flkokul terk

3 tlkokul

4 Orta okul veya dengi

5 Lise terk

6 Lise ve dengi okul

7 Üniversite terk

8 Üniversite (en az iki yıllık)

9 Dört yıllık üniversite mezunu

99. Cevap vermeyenler (veri yok missing olarak kodland1)

Gelir düzeyi: Aşağıda çeşitli gelir grubu kategorileri gösterilmiştir. Sizin hane halkınızın geliri bu kategorilerden hangisine denk gelmektedir (bütün ek gelirleri de hesaba katınız.).
$\begin{array}{llll}1 & 2 & 3 & 4\end{array}$
C D
5
$\begin{array}{lll}6 & 7\end{array}$
$\begin{array}{ll}9 & 10\end{array}$
F 